\title{
http://dx.doi.org/10.18778/2080-8313.18.10
}

Agata Chutnik

(Uniwersytet Łódzki)

\section{SPÓR O WILNO: WIELOŚĆ OBRAZÓW}

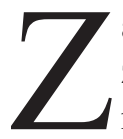

anim przejdę do części zasadniczej mojego artykułu, uważam za niezbędne dołączenie dwóch uwag o charakterze wstępnym, mających wpływ na kontekst tego tekstu, który prawdopodobnie nie jest znany Czytelnikowi. W pierwszej kolejności pragnę zaznaczyć to, że w gronie historycznym, które reprezentuje większość Autorów niniejszego tomu, ja mam wykształcenie socjologiczne i pracuję na nieco innym materiale niż większość historyków, zajmujących się tematyką losów Polaków na Wschodzie. Zasadne wydaje się tutaj odwołanie do opinii P.L. Bergera: ,gdy tylko socjolog zwraca się od teraźniejszości ku przeszłości, jego zainteresowania z wielkim trudem dają się odróżnić od zainteresowań historyka". Komentarz ten zdaje się być słuszny, gdyż każde zjawisko socjologiczne istnieje przy określonych uwarunkowaniach historycznych, a Wilno, do obrazów którego będę się odwoływać, stanowi wielokulturowy fenomen, źródła którego należy szukać właśnie w wydarzeniach historycznych i pamięci zbiorowej. Co więcej, otrzymywany materiał również najpełniej odpowiada temu okresowi czasu, w którym został zebrany, jakkolwiek jego wartość może być ważna i aktualna jeszcze przez długi czas.

Przygotowując ten artykuł bazowałam na materiale empirycznym, który zebrałam do mojej pracy doktorskiej. Poddałam w niej analizie łącznie 40 wywiadów autobiograficznych, które przeprowadziłam w latach 2011-2013 wśród młodych litewskich Polaków, u których pojawiła się możliwość podjęcia studiów w Polsce i którzy z tej możliwości skorzystali. Byli to studenci i absolwenci wybranych polskich uczelni (w Łodzi, Warszawie i Lublinie), którzy w chwili wywiadu przebywali w Polsce. Zdecydowanie największa część wywiadów została przeprowadzona w Warszawie, co mogło mieć również wpływ na otrzymany materiał. Wywiady przeprowadzałam według założeń i zasad wywiadu zgodnych z metodologią F. Schuetze, jednak zdarzało się, że przekształcały się one w pogłębione wywiady swobodne. Badania związane były ze zmianami w tożsamości młodych litewskich Polaków pod wpływem przyjazdu do Polski na studia, podejmowanymi strategiami radzenia sobie w nowym środowisku wobec występujących

\footnotetext{
${ }^{1}$ P.L. Berger, Zaproszenie do socjologii, Warszawa 2001, s. 27.
} 
różnic (w tym różnic kulturowych) i modelami przebiegu ścieżek biograficznych w oparciu o różną długość trwania szoku po przyjeździe, przekładającą się wielokrotnie na przystosowanie się do nowego środowiska bądź wchodzenie w sytuację trajektoryjną, będącą poza obszarem kontroli narratorów. W rezultacie badań określiłam też czynniki, które miały wpływ na obrane przez narratorów decyzje zmieniające ich tożsamość, poczynając od rodzaju motywacji i podłoża wyjściowego, a na ostatecznych planach dotyczących miejsca pobytu kończąc, a także zaproponowałam możliwości zastosowania odpowiednich działań, mogących przyczynić się do lepszego przystosowania się narratorów w kraju goszczącym i wykorzystania ich potencjału wyjściowego w Polsce. Prezentowany artykuł stanowi zatem swoistego rodzaju wartość dodaną, początkowo niezaplanowany rezultat badań związany $\mathrm{z}$ występowaniem tła historycznego w wypowiedziach moich narratorów. Kontekst wzajemnych stosunków międzynarodowych, a także odwoływanie się do pamięci zbiorowej, odgrywają tu niezwykle ważną rolę. To uwarunkowania historyczne i sytuacja geopolityczna stanowią kontekst ich życia, są naturalną częścią ich tożsamości. Urodzenie w polskiej lub mieszanej rodzinie na Litwie, w mniejszości narodowej, implikuje odwoływanie się do większej wspólnoty wyobrażonej i wikła w dylematy rozumienia swojej historii w cieniu grupy dominującej. Tematyka Wilna w sposób natychmiastowy uruchamia dylematy związane z kwestią poczucia przynależności, pamięci zbiorowej czy świadomości historycznej. Wielowątkowość wypowiedzi narratorów ułatwia śledzenie zmian dotyczących tak ich postrzegania określonych obrazów, jak i ich stosunku do przeszłości, teraźniejszości i przyszłości.

Druga uwaga o wstępna dotyczy nazewnictwa stosowanego przeze mnie wobec grupy, którą reprezentują moi rozmówcy. Jestem zdania, że na Litwie wykształcił się specyficzny modus kulturowy odmienny od kultury macierzystej w Polsce. O odmienności owych grup wzmiankują zresztą niektórzy badacze tego tematu ${ }^{2}$. Z przeprowadzonych przeze mnie badań wynika, że mniejszość polska na Litwie ma znamiona specyficzności i nie należy jej bezkrytycznie utożsamiać z kulturą w Polsce, choć wszelkiego rodzaju odwołania i porównania są niewątpliwie słuszne. Dlatego pisząc tak o całej grupie, jak i o poszczególnych moich rozmówcach, będę używała terminu „litewscy Polacy”. Dla większej przejrzystości i wartkości tekstu będę posługiwała się również terminem „mniejszość polska na Litwie”, rozumiejąc go jako wyrażenie synonimiczne do „litewskich Polaków”. Unikam jednocześnie określenia „Polacy z Litwy” dla badanej grupy, które mimo

${ }^{2}$ Zob.: R. Dzwonkowski, O. Gorbaniuk, J. Gorbaniuk, Świadomość narodowa młodzieży polskiego pochodzenia z bytego ZSRR studiującej w Polsce, Lublin 2002; M. Głowacka-Grajper, Rodacy - cudzoziemcy. Młodzi Polacy z Litwy, Białorusi i Ukrainy na studiach w Polsce, [w:] E. Nowicka, S. Łodziński (red.), Kulturowe wymiary imigracji do Polski. Studia socjologiczne, Warszawa 2007; C. Żołędowski, Studenci zagraniczni w Polsce. Motywy przyjazdu, ocena pobytu, plany na przyszłość, Warszawa 2010. 
wykorzystywania przy samookreślaniu członków grupy - według mnie - nie oddaje jej specyficznego charakteru. Wyjątkiem użycia tego wyrażenia są cytaty przywoływane z wypowiedzi moich narratorów, w których używają ich oni do określenia siebie lub całej grupy. Chciałabym podkreślić, że nie używam terminu „litewscy Polacy” w znaczeniu wartościującym lub pejoratywnym - wręcz przeciwnie, w określeniu tym widzę bogactwo kulturowe, potencjał, a przede wszystkim cechę normatywną, charakterystyczną dla tej wspólnoty³.

Poniższe rozważania będą związane z obrazami Wilna przedstawionymi przez narratorów podczas wywiadów. Są to obrazy różnorodne i tę wielość podejść, zanurzonych w kontekście historycznym i ściśle z nim powiązanych, będę starała się oddać na przykładzie cytatów z wypowiedzi narratorów. Obrazy te pokażą, jak bardzo historia jest istotna, szczególnie we współczesnej debacie publicznej i stosunkach międzyludzkich, pomimo częstych deklaracji, że w życiu codziennym nie gra ona obecnie roli ${ }^{4}$.

Wilno pełni ważną rolę tak dla litewskich Polaków, jak i Litwinów. Przez Litwinów rozumiane jest ono jako historyczna stolica państwa, kolebka litewskości, zaczątki państwa litewskiego. Dla litewskich Polaków z kolei Wilno to często miejsce identyfikacji i ojczyzna prywatna, miejsce zamieszkiwania ich przodków, „ojcowizna”. Istotny jest też kontekst ogólny. Z formalnego punktu widzenia Wilno to przede wszystkim stolica kraju, ośrodek podejmowania decyzji politycznych na szczeblu państwowym. Litewscy Polacy zamieszkują zwarcie jego obrzeża i okoliczne miejscowości, ze przyczym historycznych pod względem demograficznym ustępując innym grupom narodowościowym w obrębie samego miasta. Trzeba jednak pamiętać, że choć litewscy Polacy zamieszkują obecnie tereny skoncentrowane wokół Wilna, zaś w mniejszej mierze samo miasto, to bliskie sąsiedztwo dwóch grup narodowych może powodować występowanie napięcia wywołanego brakiem poczucia bezpieczeństwa i, potencjalnie, obawą dotyczącą ewentualnego przejęcia władzy przez przedstawicieli mniejszości polskiej na Litwie na szczeblu samorządowym czy ogólnokrajowym.

Co charakterystyczne, obie grupy rywalizują ze sobą o prawo do ziemi na zasadzie ekskluzywnej, odwołując się do pojęcia „ich” Wilna. Wydarzenia historyczne wzmacniają jedynie te zapędy. W tle debat publicznych, ale też $\mathrm{w}$ indywidualnych rozmowach na temat Wilna, kwestia jego przynależności (kto komu odebrał?; kto był okupantem, a kto okupowanym?, do kogo miasto należy kulturowo i historycznie?) jest nieustannie obecna. Wilno stanowi stałe źródło sporów obu grup, nie tylko odłamów nastawionych nacjonalistycznie. Hasło „Wilno nasze”

${ }^{3}$ Spodziewam się, że podobne znamiona specyficzności być może można obserwować również wśród innych grup mniejszościowych zamieszkujących terytorium grup dominującej kulturowo, a oderwanych od ojczyzn historycznych.

${ }^{4}$ Por.: A. Łada, J. Kucharczyk, A. Fuksiewicz, Obok siebie. Wzajemne postrzeganie się Polaków i Litwinów, Warszawa 2013. 
z jednej strony, z drugiej zaś sarkastyczne „Lietuva tevynė mūsų, pusė lenkų, pusė rusų” („Litwa, ojczyzna nasza, w połowie Polaków, w połowie Rosjan”) weszło do kultury jako trwały jej element, chociaż trzeba zaznaczyć, że nie używa się go wobec najbliższego kręgu przyjaciół. Istnieje krąg „,swoich” i ,obcych” narodowościowo, a obrazy wytwarzane na temat każdej z tych grup nie zazębiają się, nawet pomimo faktycznej bliskiej znajomości kogoś z ich członków. Stąd wciąż żywe pytanie „czyje Wilno?”, które stanowi coś pośredniego pomiędzy zaczepką a żartem - i odpowiedź „Wilno nasze”, traktowane pół serio, pół żartem. Owa wymiana zdań na temat Wilna raz jest żartem, raz wyrzutem, raz zarzutem. Zawsze jednak w sposób bardzo silny angażuje emocjonalnie obie strony wymiany zdań. Jak mówi jedna $\mathrm{z}$ moich narratorek:

jedni krzyczą czy Wilno jest polskie, drudzy, że Wilno jest litewskie [...] Wszyscy tak mówią. I Litwini i, wiesz, i Polacy [...]. Właśnie - od najmłodszych lat to słyszę. I wiesz, w jakiejś formie, wiesz, /y/ żartu na początku to było, wiesz, jak byłaś mała, a teraz rozumiesz, co//co to ma znaczyć6.

Kwestię chęci zawłaszczenia Wilna pod względem leksykalnym i semiotycznym widać również na rozgraniczeniu na „Wilno nasze” - „Wilno wasze”. Takie postawienie w zdecydowanej opozycji ma mocno dychotomiczny charakter typu: jeśli A to nie B, jeśli B to nie A. Wybór jednej z opcji wyklucza możliwość wyboru drugiej i językowo stawia silny znak demarkacyjny na określonym terytorium. W tym kontekście charakterystyczne jest również wytworzenie i używanie własnego nazewnictwa, stosowanego przez obie grupy wobec siebie nawzajem. Litwini stworzyli określenia litewskich Polaków, litewscy Polacy zaś określenia Litwinów. Zarówno w jednym, jak i drugim przypadku, mają one charakter raczej pejoratywny i używane są głównie na terenie Wileńszczyzny, a zatem terenie zamieszkiwania obu grup razem.

Rozważając tematykę Wilna, trzeba wskazać też na jeden znaczący aspekt, wpływający na szersze rozumienie współczesnego konfliktu rodzącego się na jego tle. Są to media (telewizja, internet), które na Litwie (notabene również w Polsce) uważane są za jeden z najbardziej obiektywnych i wiarygodnych środków przekazu informacji. Mimo że Wilno jest źródłem napięć między litewskimi Polakami a Litwinami, jednak to media mogą stanowić platformę rozprzestrzeniania się zarówno potencjalnych sporów, jak i pejoratywnych obrazów względem określonych grup: tak litewskich Polaków w mediach litewskojęzycznych, jak i Litwinów w mediach polskojęzycznych na Litwie. Przykładem takiej działalności mediów był okres po 2011 r., kiedy można było zaobserwować wzmożoną aktywność mediów w wytwarzaniu wzajemnych negatywnych stereotypów. W badaniach, które przeprowadziłam, w naturalny sposób można prześledzić komentarze doty-

${ }^{5}$ Tłumaczenie własne, pierwsza część powiedzenia nawiązuje do początku hymnu litewskiego.

${ }^{6}$ Narratorka Edyta 
czące powrotu i tworzenia negatywnego stereotypu litewskiego Polaka, choć są też narratorzy wspominający, że media polskojęzyczne nie pozostawały na tej płaszczyźnie dłużne względem Litwinów. Narratorzy odwołują się do wywoływania poczucia zagrożenia przez litewskie media, jednocześnie nawiązując do zagadnienia przynależności Wilna i pojawiania się kwestii historii w debacie publicznej. Można powiedzieć, że w niektórych komentarzach historia ma wręcz zasadnicze znaczenie. Jeden z moich rozmówców mówi:

Tak naprawdę - cały czas ktoś wyskoczy z tą historią. Cały czas jest tak, że niby tak, że// w jakimś momencie ludzie potrafią o tym zapomnieć, ale potem ktoś wyskoczy i powie, że, nie wiem, że »Polacy zabrali od nas Wilno! Ten Piłsudski!«, czy jeszcze coś takiego! No i tak naprawdę ja myślę, że już// że już czas zapomnieć tę historię. Bo to raczej już była przeszłość. Że raczej to już było, no ale no trudno tym osobom po prostu o tym zapomnieć. Raczej ciągle jest tak, że ciągle wspomina się tę historię. Tak samo tutaj w Polsce wspomina się okres PRL i to wszystko. Tak samo u nas. Litwini wspominają, że Piłsudski zabrał im Wilno. Polacy też wspominają, że, nie wiem, no - że Wilno kiedyś tam było polskie, no i właśnie to jest takie, że, nie wiem, są napięcia tak naprawdę [...]. historia ciągle jest przewijana w mediach, ciągle wśród osób publicznych [...] media ciągle to, żeby ludzie pamiętali, żeby ludzie o tym nie zapomnieli, więc ciągle są produkowane jakieś filmy, jakieś programy. Ciągle jest przypominana ta historia, że ktoś// kto jest zły a kto dobry?

Do kwestii historii i poczucia zagrożenia związanego z możliwością odebrania władzy odwołuje się zresztą większa część moich rozmówców. Inna narratorka mówi:

Litwini ciągle wspominają /y/, że Polacy zabrali od nich Wilno. I - no nie mogą tego wybaczyć. Jakby - właśnie chyba to i bardziej// bo nie wiem jak to by było gdyby/y///gdyby to historia by inaczej, a nie byłaby. Ale to historii nie da się zmienić. Ale oni ciągle wracają do tego. Trzeba żyć teraźniejszością, a oni ciągle wracają do tego, że »o Polacy zabrali Wilno « i no i zawsze o tym. [...] No im zawsze wydaje się, że my chcemy wszystko zabrać od nich, że my jakby nie wiem, że to Wilno, że my kiedyś tam nie wiem, odłączymy się od nich jakby. Nie wiem, no ja takich myśli nie miałam nigdy. Może ktoś i ma. ((śmiech)) Że tam odłączyć Wilno od Litwy. Ale no nie. Że no właśnie, że oni takie - myślą, oni myślą tego, że my chcemy wszystkiego - jakby i że my nie chcemy jakby// że oni myślą, że jakby my mieszkamy na Litwie i nie chcemy pod ich tem// że nie chcemy się zachowywać tak jak trzeba, nie? No że jak// bo że// a nie, znaczy zaraz, że jakby jak jest państwo, jest polityka nie i że to obywatel musi zachowywać się tak, jak// jaki jest ustrój w państwie nie. I oni myślą, że my jesteśmy jakimiś buntownikami, że my tego nie chcemy, że my chcemy nie wiadomo czego, że my chcemy, żeby tam nie wiem, żeby tylko Polacy by rządzili bo tam Wilnie, czy coś tam takiego ${ }^{8}$.

Kwestia stosunków między litewskimi Polakami a Litwinami w kontekście Wilna i zdarzeń historycznych przedstawiana jest w powyższych cytatach z perspektywy przedstawiciela mniejszości polskiej na Litwie, stąd jednostronne

\footnotetext{
7 Wyw. Natasza

${ }^{8}$ Wyw. Maria
} 
dychotomiczne rozróżnienie na sprawcę i ofiarę. Jest to podejście naturalne w przypadku osoby reprezentującej grupę mniejszościową, a w przypadku wielu narratorów zakotwiczone jest ono w określonych doświadczeniach biograficznych. Istotą jest pokazanie, jak bardzo wyobrażenia narratorów dotyczące obrazów litewskich Polaków wśród Litwinów są zakorzenione w pamięci zbiorowej. Nawiązanie i ważność tematu historii jest w przedstawianych wypowiedziach oczywista. Wiąże się z wydarzeniami dwudziestolecia międzywojennego, a także obawami związanymi z okresem odzyskiwania przez Litwę niepodległości, gdyż właśnie wtedy, jak zauważa Z. Kurcz:

zmiany polityczne, kojarzone tu także z otwarciem na wielokulturowość mieszkańców Wileńszczyzny, umożliwiły Polakom i Litwinom sięgnięcie po wartości związane z własną tożsamością, wartości jednakże antagonizujące, bo zaistniałe po przebudzeniu - litewskość i polskość - stanowiły wzajemne zagrożenie? .

Rozprzestrzenianie negatywnych obrazów w mediach według moich rozmówców wywoływane jest pojawieniem się postaw nacjonalistycznych i zaostrzeniem dyskursu wobec litewskich Polaków. Na zasadzie sprzężenia zwrotnego pejoratywne obrazy te wpływają na pojawienie się takich postaw. Szczególnie wypowiedzi polityków zaangażowanych nacjonalistycznie są nośne, przyciągając uwagę mediów i wchodząc do debaty publicznej. Dlatego o okresie największego napięcia w mediach na Litwie względem litewskich Polaków jeden z moich narratorów mówi w sposób następujący:

jeżeli chodzi o tę płaszczyznę publiczną taką, o to jest często wypominane, to jest podstawowy argument Litwinów, że: < ((dobitnie do +$))$ Tak, wy do nas przyszliście, chcieliście nam odebrać pół Litwy. To teraz nie możemy wam tego odpuścić, musimy się zemścić przynajmniej, że coś złego zrobić, bo jak to było, że my, takie Wielkie Księstwo Litewskie przez Witolda rozwinięte, od Bałtyku po Morze Czarne teraz tu będzie teraz ustępowało wobec was, złodziei// bo to stereotyp Polaka na Wilnie złodziej i żulik/// No. Nie będziemy teraz tu wobec was, żulików, ustępować, jakichś ulg wam robić, nie, nie można, my musimy walczyć o swoje. My//my w końcu jesteśmy w swoim państwie, ustalamy warunki. My powiedzieliśmy tak, i tak będzie, inaczej być nie może. Wy mówcie co chcecie, już się dużo lat tutaj macie i robiliście co chcecie, teraz przyszła kolej na nas i nasze pokolenia, my teraz jesteśmy przy władzy, my zdecydujemy jak wy żyć będziecie> (+). No, i w takim stylu to się toczy rozmowa na różnych płaszczyznach, na jak na medialnym, tak i politycznym ${ }^{10}$.

Przywołuję tę wypowiedź z pełną świadomością tego, że okres największego napięcia medialnego względem litewskich Polaków mamy za sobą. Jednak przypomnienie tej sytuacji pokazuje siłę przekazu medialnego, który potrafi być nośnikiem tak mocnych i zdecydowanych obrazów. Niebezpieczeństwo polega na tym, że wielokrotne pokazywanie i powtarzanie negatywnych obrazów przekłada na

9 Z. Kurcz, Mniejszość polska na Wileńszczyźnie, Wrocław 2005, s. 14-15.

${ }^{10}$ Wyw. Krystian 
się na postawy, postawy zaś mogą przełożyć się na zachowania. Historia jest w tym wypadku zakładnikiem zachowania politycznego, rozsianego za pomocą mediów. Byliśmy i jesteśmy świadkiem tego, że obrazy te faktycznie przełożyły się na stosunek Litwinów do litewskich Polaków. W badaniach widać było, jak najbardziej wykształcone grupy Litwinów, będąc pod wpływem owej debaty publicznej i informacji medialnych, zaczęły negatywnie być nastawione do litewskich Polaków ${ }^{11}$. Natomiast skutki takich działań będą zapewne widoczne jeszcze przez długi czas, bo zmiany w zakresie utrwalonych postaw następują powoli.

Na powyższych przykładach, jednych z wielu wypowiedzi na ten temat, mogliśmy zobaczyć opinie narratorów dotyczących lub też odwołujących się do występowania kwestii historycznych w dyskursie medialnym. Poniższy fragment będzie natomiast dotyczył podziału postaw narratorów względem samego Wilna. Obrazy te są różnorodne i wielopłaszczyznowe. Niekiedy typy pojawiające się w jednej argumentacji nie wykluczają drugiej, w innym przypadku podobna argumentacja niesie za sobą inny wynik. Podejście do zagadnienia Wilna dzieli w ten sposób nie tylko głosy litewskie i polskie, ale też polskie wewnątrz samej grupy. Ze względu na fakt, że zagadnienia dotyczące Wilna nierozłącznie powiązane są z kontekstem historycznym i geopolitycznym, część moich rozmówców nawiązuje do Polski jako dodatkowego aktora w stosunkach między litewskimi Polakami a Litwinami. W punkcie tym należy zresztą zaznaczyć, że w ogóle tematyka litewskich Polaków nie występuje w odosobnieniu, ale w całym splocie różnych uwarunkowań, w których aktorów jest znacznie więcej. Przede wszystkim są to oczywiście Litwini jako grupa dominująca, ale we wzajemnych relacjach niezwykle ważną rolę odgrywa także Rosja i mniejszość rosyjska na Litwie. Polska jako państwo, do którego litewscy Polacy odwołują się, a która dodatkowo pełni rolę dużego i ważnego gospodarczo sąsiada Litwy, gra w stosunkach między litewskimi Polakami a Litwinami szczególną rolę. Stanowi z pewnością ważny punkt odniesienia, nie tylko ze względu do nawiązań do historii. Nie jest też jasne wzajemne oddziaływanie stereotypów litewskiego Polaka a Polaka z Polski, chociaż wiadomo, że ono występuje. Istotnym aktorem jest z pewnością również mniejszość litewska w Polsce jako grupa komparatywna na płaszczyźnie praw i warunków do utrzymania swojej odrębności, a także Unia Europejska, która daje wiele możliwości, ale też nakłada pewne ograniczenia i wywołuje czasem nieuświadomione lęki związane z istnieniem w obrębie jednej większej całości. Jako dodatkowych aktorów można byłoby wziąć pod uwagę również inne państwa ościenne - z Białorusią na czele. A zatem litewscy Polacy nie żyją jako grupa w „próżni” i każdy ze wspomnianych aktorów, rozumianych jako inna grupa, ma określony wpływ na jej funkcjonowanie.

\footnotetext{
${ }^{11}$ Zob.: A. Łada, J. Kucharczyk, A. Fuksiewicz, dz. cyt.
} 
W uzyskanym materiale empirycznym można wyszczególnić trzy rodzaje postaw narratorów względem kwestii Wilna. Pierwszą z nich prezentują narratorzy, którzy odwołują się do historycznej przynależności Wilna do Polski, często jednak odrzucając hasło „nasze Wilno”. Nie jest wykluczone, że odcięcie się od tego hasła pojawia się jako reakcja pobytu w Polsce, gdzie narratorzy muszą tłumaczyć sytuację mniejszości polskiej na Litwie swoim mniej zaznajomionym z tematem kolegom z Polski, którzy to koledzy niejednokrotnie całość swojej wiedzy na temat Litwy czerpią z telewizji i doniesień o szkalowaniu mniejszości polskiej czy aktach dyskryminacji przejawianych wobec niej. Spotykając się z komentarzami osób, które mówią o Wilnie (jak i ogólnie o Kresach Wschodnich) jako o polskiej utraconej własności, która powinna trafić z powrotem w polskie ręce, reagują oporem i poczuciem braku zrozumienia ${ }^{12}$. Możliwe zatem, że w wyniku pobytu w Polsce i w konfrontacji do zakusów nacjonalistycznych obecnych w Polsce hasło przynależności Wilna musi zostać odrzucone. Niektórzy narratorzy reprezentujący pierwszą grupę w ogóle takich tendencji nigdy nie mieli. Niezależnie od wszystkiego, konfrontacja z polskim nacjonalizmem czy paternalizmem jest jednak w wypowiedziach obecna. Może ona dotyczyć aktywnych postaw lub sentymentów do dawnych ziem polskich lub odnosić się do sentymentalnych wycieczek Polaków do Wilna, gdzie w odczuciu moich narratorów pojawia się nieuświadomiona chęć przywłaszczenia sobie Wilna przez Polaków z Polski. Jedna narratorka mówi w tym kontekście:

też co ciekawe, że mimo tego podkreślania takiej całej pol//polskości, od, nie wiem, to mnie właśnie// moje środowisko, tak?, całe, na przykład bardzo się oburza, obrusza właśnie na wycieczki polskie, które przyjeżdżają i to jest, »ach, nasze, polskie Wilno«, tak? Nie wasze one! Nie wasze, jakby// bunt przeciwko temu, że - często w przewodnikach polskich, tak?, pomija się tych nieszczęsnych 50 lat, kiedy w Polsce// kiedy Litwa była// Litwa była w Związku Radzieckim, tak? Że to co sowieckie w ogóle nie istnieje, że się dos//dostrzega tylko to, co polskie, tak? Że to jest polski napis, polska studzienka, tak?, z napisem Wilno, tak?, że »ach, ci Polacy tak pięknie mówią«, tak, że jakby//jakby to były jakieś egzotyczne zwierzęta, tak? I wsze// /mmm/ tak, i my się właśnie czasami jak spotykamy - tak z przyjaciółmi, teraz to znowu nawiązały się mam jakieś relacje takie z//z nowymi kole//koleżankami w Wilnie, to się tak czasami ((niezrozumiałe jedno słowo)) że to jest takie niesmaczne, tak? Że cały czas się mówi o konfliktach polsko-litewskich, tak?, ale akurat całe to podkreślanie takiej tej polskości, takiej, która minęła, która była kiedyś, też raczej jest źródłem pewnych antagonizmów, tak? No bo Polacy wileńscy mówią świetnie po rosyjsku, lubią rosyjską muzykę, tak?, dobrze wspominają te czasy, kiedy był Związek Radziecki, tak?, i to jest też w takiej innej historii, tak?, którą chce się w jakiś sposób tak wymazać, tak? Że to był przypadek, tak? Tak samo, jak się uważa, że to jest przypadek, że jest Litwa, tak naprawdę powinna być Polska. Nie. To się zmieniło. Lwów nie jest już polski, Wilno nie jest też już polskie, tak? ${ }^{13}$.

12 http://kresy24.pl/64345/wilnodonbas-uderzymy-w-litwe-razem-z-rosjanami/ (dostęp z 28 II 2015 r.); http://wyborcza.pl/magazyn/1,143551,17404970,Wodzu_prowadz_na_Wilno_html (dostęp z 14 II 2015 r.)

13 Wyw. Joanna. 
W powyższym cytacie narratorka nawiązuje do historii, która uformowała i zmieniła Wilno, rozdzielając je od „,polskiej Macierzy”. Zauważa brak rozpoznania tego tematu przez Polaków z Polski i pewnego rodzaju arogancję z ich strony, kiedy przyjeżdżając do Wilna hołubią znaki bytności jedynie swojej kultury. Niedostrzeganie innej spuścizny kulturowej narratorzy oceniają negatywnie, a w innych wypowiedziach podkreślają swoją inność od rodaków z Polski i brak chęci dzielenia się z nimi być może wielokulturowym, ale z całą pewnością nie jedynie polskim Wilnem. Co ciekawe, śledząc cały wywiad z przytoczoną narratorką, przyznaje ona prawo do określenia Wilna jako własne nie tylko swojej grupie, jednak zdecydowanie odcina się od zakusów Polaków z Polski do Wilna.

Do drugiej grupy należą narratorzy, którzy uważają, że „Wilno jest polskie”. Różnica pomiędzy tą a wcześniejszą grupą polega na tym, że narratorzy tworzący drugą grupę traktują Wilno raczej w sposób ekskluzywny, odbierając prawo do niego również innym grupom, w tym litewskiej grupie dominującej. Widać to w wypowiedzi narratorki, która odnosząc się do stosunków polsko-litewskich mówi:

ten problem z Wilnem chyba taki jest najbardziej aktualny. Chociaż mówię, zawsze się zastanawiam, czemu Wilno jest stolicą Litwy. Bo przecież, no nie wiem, Wilno jest polskie, no nadal, naprawdę! Bo, nie wiem, tak się na przykład czuje, że zawsze idę, nie, gdzieś tam zwykle i zawsze słyszę ten język polski, no dużo tego jest, tak?, na przykład, gdzieś tam w Kownie, czy gdzieś tam w innych miastach litewskich, no to więcej jest takiej litewskości powiem, właśnie mówię tak się długo zastanawiałam, czemu Wilno jest stolicą Litwy ${ }^{14}$.

W dalszej części wywiadu narratorka zaznacza, że to, że kulturowo Wilno jest dla niej polskie nie oznacza, że istnieją jakieś tendencje autonomistyczne.

W wywiadach narratorzy, którzy stronią od wyrażania własnego poglądu na rzecz wyjaśniania genezy konfliktu wokół Wilna, stanowią trzecią grupę odwołań związanych z obrazami Wilna. W grupie tej po raz kolejny narratorzy powracają do historii, wyjaśniając na jej podstawie sytuację bieżącą bez znaczącego osobistego zaangażowania w którąś ze stron późniejszego konfliktu. Jedna z narratorek mówi:

a Polacy też mówią zawsze, że Wilno jest nasze, i to jest uzasadnione historycznie, ponieważ jakby język polski był w pewnym momencie jakby językiem elit i /y/ nawet jak tak myślę, że nawet jak w//w//w tym Wilnie byli Litwini, Białorusini i tak dalej wtedy, tam, tamtejsi ówcześni, że oni// że mówienie po polsku było oznaką takiego wykształcenia, prawda?, tak jak w innych miejscach po francusku, albo jak tam też po francusku i tak dalej, w każdym razie należało się wypowiadać po polsku, żeby mówić po polsku, żeby nie uznać// żeby nie zostać uznanym za chłopa. I ten /yy///i sam język chyba się usamodzielnił litewski dosyć późno i //i to Wilno, które przez tyle wieków mówiło po polsku i jest uznawane za te wszystkie oczywiście i majątkowo i tak dalej, te wszystkie, $/ \mathrm{mm} /$ bardzo dużo jakby /yyy/ jak to się nazywa, no nie wiem, nieruchomości należy rzeczywiście do Polaków, ale też to nie jest

${ }^{14}$ Wyw. Edyta. 
taka łatwa sprawa, mi się wydaje, że skoro mieszkańcy Wilna na przykład, gdzie się toczyło takie życie kulturalne jakby /yy/ które zaczęło się mniej więcej właśnie w takim w tamtym okresie kiedy zaczynała się pewna wolność $i$ tak dalej i ta edukacja była ważniejsza, i jakby cała cywilizacja rosła, prawda?, i rosła też po//powolutku na Litwie/ i mnie się wydaje, że jak//jak się mieszka w mieście, gdzie od dwustu lat lepiej mówić na przykład po polsku niż po litewsku, i wszyscy mówią w tym języku polskim, to też ludzie się deklarują jako Polacy, i mnie się wydaje, że jest Polaków na przykład, że naprawdę było dużo Polaków, ale naprawdę było też dużo nie-Polaków, tylko takich, którzy się po//powoływali do tej kultury wyższej, prawda?, która wtedy była// która wtedy była jedynie dostępna w języku polskim. I chcieli i dążyli do niej po prostu. I i ten język litewski właśnie dosyć późno wszedł na salony po prostu i no stąd mi się wydaje, że jest taka dychotomia, prawda?, że tam są (((z przekąsem))) pan, czy pani Polka i tak dalej, i że// i że niby Polacy są tacy zarozumiali. No a// no i tak wracając jakby tym kołem z tego wywodu, że Polacy z kolei twierdzą, że Wilno zawsze było nasze ${ }^{15}$.

W powyższym cytacie widoczny jest przykład wykorzystania wiedzy historycznej do wytłumaczenia zjawisk funkcjonujących współcześnie. Narratorka wraca do wcześniejszych okresów, by wyjaśnić występowanie określonych zjawisk współczesnych, jednocześnie nie zdradzając, jakie jest jej zdanie na ten temat. Nawet zapytana o ten aspekt w dalszych częściach wywiadu, nie ujawnia się $\mathrm{z}$ tą informacją.

A zatem możemy mówić o różnych podejściach do Wilna i kwestii poczucia jego przynależności wśród badanych przeze mnie postaw i opinii litewskich Polaków. Co zrozumiałe, wśród moich rozmówców poglądy te wiążą się z zagadnieniem ich poczucia narodowego i stosunku do Litwinów jako grupy dominującej. Warto jednak podkreślić, że w żadnym stopniu rodzaj prezentowanych podglądów, nawet w ujęciu bardziej radykalnym, nie wpływa na poczucie lojalności względem państwa litewskiego, nawet wówczas, gdy narratorzy do niektórych działań Litwy jako państwa odnoszą się krytycznie. Badani przeze mnie litewscy Polacy są i czują się obywatelami Litwy w pełnym tego słowa znaczeniu, choć część z nich uważa, że ich prawa jako mniejszości nie są respektowane. Co równie ciekawe i warte podkreślenia, w wyniku przyjazdu do Polski w wywiadach pojawia się rys odcięcia od kultury polskiej i rodaków z Polski. I historia, brak wiedzy o niej i brak jej zrozumienia przez Polaków z Polski gra w niej, po raz kolejny, niezwykle ważną rolę.

${ }^{15}$ Wyw. Eliza 
Agata Chutnik

\section{THE DISPUTE OVER VILNIUS: THE MULTIPLICITY OF IMAGES}

Vilnius plays an important role both for Lithuanian Poles and Lithuanians. By Lithuanians, it is understood as the historical capital of the state, the beginnings of the Lithuanian state. For Lithuanian Poles, in turn, Vilnius it is often a place of identification and a private homeland, a place of residence their ancestors. This article relates to the images of Vilnius presented by narrators during the interviews. I will try to illustrate the multiplicity of approaches using quotes from narrators. These images will show how important history is, especially in contemporary public debate and interpersonal relations, despite frequent declarations that it is currently not playing a role in everyday life.

Słowa kluczowe: kultura pamięci, stosunki polsko-litewskie, Wilno

Keywords: culture of remembrance, Polish-Lithuanian relations, Vilnius

\section{BIBLIOGRAFIA}

\section{Opracowania:}

Berger P.L, Zaproszenie do socjologii, Warszawa 2001.

Dzwonkowski R., Gorbaniuk O., Gorbaniuk J., Świadomość narodowa młodzieży polskiego pochodzenia z byłego ZSRR studiującej w Polsce, Lublin 2002.

Kurcz Z., Mniejszość polska na Wileńszczyźnie, Wrocław 2005.

Łada A., Kucharczyk J., Fuksiewicz A., Obok siebie. Wzajemne postrzeganie się Polaków i Litwinów, Warszawa 2013.

Nowicka E., Łodziński S. (red.), Kulturowe wymiary imigracji do Polski. Studia socjologiczne, Warszawa 2007.

Żołędowski C., Studenci zagraniczni w Polsce. Motywy przyjazdu, ocena pobytu, plany na przyszłość, Warszawa 2010.

\section{Publikacje internetowe:}

http://kresy24.pl/64345/wilnodonbas-uderzymy-w-litwe-razem-z-rosjanami/.

http://wyborcza.pl/magazyn/1,143551,17404970,Wodzu_prowadz_na_Wilno_html. 